\title{
Çocukların Epistemolojik Görüşlerinin İncelenmesi
}

\section{Gökhan GÜNEŞ*}

Öz: Felsefenin bilgiyi incelediği alan epistemoloji olarak geçmektedir. Daha önce yapılan epistemoloji çalışmaları incelendiğinde büyük bir bölümünün ilköğretim, lise ve üniversite öğrencileri ile yapıldığg görülmektedir. Bu nedenle okul öncesi çocuklarının epistemolojik görüşlerinin uygulamaya dayalı etkinlik setleri ile ölçülmesinin, ilgili alan yazıma önemli katkılar sağlayacağı düşünülmektedir. Buradan hareketle, araştırmanın amacı okul öncesi dönem çocuklarının epistemolojik görüşlerinin incelenmesidir. Araştırmanın deseni nicel, yöntemi ise betimsel nitelikli tarama modelidir. Çalışmada veri toplama araçları olarak Güneş (2014) tarafından geliştirilen Epistemolojik Etkinlikler Seti (EES) ve Çocuklar İçin Epistemolojik Görüş Ölçeği (ÇİEGÖ) kullanılmıştır. Çalışma Ankara ilinde bulunan üç devlet anaokulundan, 73 kız ve 68 erkek çocuk olmak üzere toplam 141 çocukla yürütülmüştür. EES sonuçları genel olarak değerlendirildiğinde, çocukların büyük oranda otoriteye bağlı ve bilginin değişimine inandıkları tespit edilmiştir. Bununla beraber çocukların ÇİEGÖ’ den aldıkları toplam puan 56.58 ve ölçek değer aralık puanı ise 2.26 ile dogmatik felsefi düşünme sınırları içinde oldukları görülmektedir. Buna karşın, ÇİEGÖ’ deki skeptik felsefi düşünme sınırları için ölçek değer aralığının 2.34 olması ve bilginin değişimi ile akıl yürütme alt boyutlarında skeptik düşünce eğilimi göstermeleri, çocukların skeptik felsefi düşünceye yakın oldukları şeklinde yorumlanabilir.

*Hakkari Üniversitesi Eğitim Fakültesi, İlköğretim Bölümü Okul Öncesi Öğretmenliği ABD, Hakkari, gokhangunes@hakkari.edu.tr 
http://dx.doi.org/10.23891/efdyyu.2017.9

Anahtar Kavramlar: Okul öncesi eğitim, felsefe, epistemolojik görüşler, dogmatik felsefi düşünce, skeptik felsefi düşünce

\section{Investigation Children's Epistemological Views}

Abstract: Epistemology can be defined the branch of philosophy concerned with the theory of knowledge. It can be seen that large part of previously epistemology studies carried out with students come from elementary schools, high schools and universities. Therefore, measuring of preschool children's epistemological views by help of the applied epistemological activities set to provide important contributions to the literature. From this point of view, the purpose of the research is to examine the preschool children's epistemological thoughts. Descriptive survey and quantitative methods are used in this study. Set of Epistemological Activities (SEA) and the Epistemological Views Scale for Children (EVSC) were used as a research tools for collecting data. The study was carried out with 141 children ( 73 girls and 68 boys) from 3 state preschools. The total EVSC score is 56.58 and their scale interval score of 2.26 showed that they tended towards dogmatic philosophical thought. On the other side, border of sceptical thoughts in the scale interval is 2.34 and also children have sceptical thoughts at subscale of change of the knowledge and reasoning interpreted as children close to sceptical philosophical thought.

Key Words: Pre-school education, philosophy, epistemological views, dogmatic philosophical thought, sceptical philosophical thought 


\section{Giriş}

İnsanı diğer canlılardan ayıran en temel özellik düşünebilme yeteneğidir. İnsanın doğduğu andan itibaren bilişsel olarak gelişim gösterir. Biliş, ileri zihinsel süreçleri içeren işlemler bütünüdür. Zihinsel süreçler; dikkat, alg1, bellek, dil gelişimi, okuma ve yazma, problem çözme, anımsama, düşünme, akıl, yaratıcılık vb. kapsayan geniş bir terimdir. Bilişsel gelişim; doğumundan başlayarak, çevremizdeki dünyayla etkileşimimizi sağlayan ve dünyamızı anlamamızı yarayan bilginin edinilip kullanılmasına, saklanmasına, yorumlanarak yeniden düzenlenmesine, değerlendirilmesine yardım eden, bütün zihinsel süreçleri içine alan bir gelişim alanıdır (Mesleki Eğitim ve Öğretimi Güçlendirme Projesi-MEGEP, 2007).

Piaget (1970) öğreneni merkeze alarak oluşturduğu bilişsel gelişim kuramında, çocukları bilginin pasif alıcıdan çok aktif yapılandırıcısı olan bilim adamları gibi görmektedir. Piaget (1964) bilişsel gelişim kuramında, bireylerin geçmiş yaşantıları yoluyla elde ettikleri depo bilgileri olduğunu savunmakta ve bu depo bilgileri zihindeki şemalar (schema) olarak tanımlamaktadır. Piaget' e göre insan zihni eski ve yeni bilgiler arasında dengede olma eğilimindedir, yani yapılandırdığı yeni bilgiler eski öğrendikleri ile tutarlı olmak zorundadır. Yeni bilgileri zihin içinde dengeli olarak konumlandırma çabası Piaget tarafından denge durumu/denge hali (equilibrium) olarak kavramsallaştırılmıştır. Piaget (1964), denge haline ulaşılmasında zihinde yeni bilgilerin uyum (adaptasyon) sürecinin aktif olduğunu savunmaktadır. Uyum süreci ise özümseme (assimilation) ve düzenleme (accomadation) 
http://dx.doi.org/10.23891/efdyyu.2017.9

ISSN:1305-020

süreçleri ile şekillenmektedir. Özümseme, kısaca yeni bilgilerin zihindeki şemalarla entegrasyon süreci olarak tanımlanabilir. Çocuk yeni bilgi ile eski bilgileri arasında bağ kurar ve oluşan bu köprü aslında en başta tanımlanan denge durumuna gelme çabasıdır. Buna karşın, her zaman edinilen yeni bilgiler zihinde hali hazırda oluşmuş şemalara uyum sağlamayabilir. Uyum sağlanamadığı için zihindeki denge durumunda bozulma gerçekleşir. Zihindeki dengesizlik durumu, Piaget için yeni bilgilerin aktif bir şekilde yapılandırılması anlamına gelmektedir. $\mathrm{Bu}$ dengesizlik durumu aktif öğrenme için olumlu bir sürecinde başladığı anlamına gelmektedir. Oluşan bu dengesizlik durumunun aşılması için zihin düzenleme sürecine geçer. Düzenleme sürecinde, zihin, yeni bilgi için yeni bir şema düzenleyerek denge halini tekrar kurmuş olur, bu zihinsel işlemlerin sonunda da zihinde bilgilerin oluşturduğu şemalarda artış ve buna bağlı olarak kavramsal bilgi gelişimi sağlanmış olur.

Kavramsal bilgi gelişiminde iki aşamada etkilidir. İlk aşama sembolik (kavram öncesi) (2-4 yaş) dönem ikinci aşama ise sezgisel dönem (4-6 yaş) olarak kabul edilebilir. Sembolik evrede, dil gelişimi hızlıdır, fakat kendilerine özgü bir dil kullanırlar. Bu dönemin en önemli özellikleri oyunlarında görülmektedir, herhangi bir nesneyi oynamak istedikleri her şey olarak kabul edebilirler. Örneği bir terlik onun kamyonu, bir çubuk atı ya da kılıcı, cetveli ise uçağı ya da silahı olabilir. Bu çocuğun o anki hayal dünyasına göre şekillenmektedir. Benmerkezci düşünce bu dönemde çok etkilidir. Çok somut düşünürler ve bir şeyler onların varlığından bağımsız değildir. Bir şeyin çocuklar için olması, görünmesine, dokunulmasına ya duyulmasına bağlıdır. Sezgisel dönemde ise, kavram oluşumları, problem çözüm süreçlerine karşı geliştirdikleri stratejiler dikkat çekicidir. Çocuklar bu evrede mantıksal-analitik çıkarımlar yerine sezgileri ile problemlere ve ya olaylara yaklaşırlar. Ben-merkezci düşünme 
http://dx.doi.org/10.23891/efdyyu.2017.9

ISSN:1305-020

yapısı bu evrede de devam eder. Geliştirdikleri mantığın altında benmerkezci düşünme yatmaktadır. Bunun yanı sıra nesnelerin tek bir özelliğine odaklanırlar bu durumda nesne korunumunu kaçırmalarına neden olur. Çocukların sezgisel dönemde, azlık çokluk kavramlarında, nesne korunumu tam gelişmediği için hatalar yapabildikleri gözlemlenmektedir. Bu duruma verilen en yaygın örnek, eşit miktardaki suyun, çocuklara göre uzun bardakta daha çok, kısa ama geniş bardakta ise daha az olmasıdır.

Çocukluktan itibaren başlanın kavramsallaştırma gerçekte öğrenme-bilme güdüsünün yansıması olarak değerlendirilebilir. Aristoteles’ e göre insan, doğası gereği bilmek ister (Aristotle, 2004). Aristoteles' in MÖ 350' lerde insanın doğasına dair önermesi hala günümüzde geçerliliğini korumaktadır. Bilmek, akıl yürütmek ve muhakeme yeteneğini kullanabilmek, yaşamın süregelen dinamikleri içinde her zaman farklı anlamlar yüklenen ve birçok sonuç doğuran bir gerçeklik olarak karşımıza çıkmaktadır. Buradan hareketle, evrene ilişkin tüm anlama gayretinin, düşünmek, bilmek ve bilginin içinde barındırdığı kavramları ortaya çıkarabilmek olduğu söylenebilir.

Bilgi kuramının kurucuları arasında yer alan Locke' a göre bilgi kuramı, bilginin kökenini, doğruluğunu ve sınırlarını, buna göre de inanç, kanı ve yargılarımızın derece ve temellerini araştırır (Aktaran, Kale, 2009). Bilgi, genel bir kavram(sallaştırmadır) ve bilgi bir şeyin bir şey olarak kavranması olarak açıklanabilir (Topdemir, 2011). Felsefenin bilgiyi incelediği alan ise epistemolojidir. Hofer ve Pintrich (2002) epistemolojiyi insan bilgisinin kaynağı, doğası, sınırlılıkları, sistemi ve doğruluğu olarak tanımlamaktadır. Epistemoloji açısından en kritik konular, Perry (1999), King ve Kitchener (1994) ve Hofer ve Pintrich (2002) tarafından, bilginin doğasına olan inanç ve bilmenin doğasına olan inanç olarak ifade edilmektedir. 
http://dx.doi.org/10.23891/efdyyu.2017.9

ISSN:1305-020

Epistemolojik görüssler bilme, bilgi ve kişinin bu sorulara aradığı cevaplar olarak kabul edilebilir. Bu sorulardan bazıları, "bilgi nedir?”, “bilgi nasıl kazanılır?”, “bilginin kesinlik derecesi nedir?”, “bilgi için sınırlar ve kriterler nelerdir?”, "bilgi, öğrencinin dışında gerçekleşen ve disiplin alanlarının otorite figürleri (uzmanlar) tarafından öğrenene yüklenmesi sonucu kazanılan bir şey midir yoksa disiplin alanlarının ışığında etkileşim ile mi elde edilen bir şeydir?" şeklinde sıralanabilir (Brownlee, Purdie ve Boulton-Lewis, 2001; Hofer ve Pintrich, 1997; Ravindran, Greene ve DeBacker, 2005). Schommer (1990) ise epistemolojik görüşü, bireylerin bilginin ne olduğu, bilme ve öğrenmenin nasıl gerçekleştiği konusundaki görüşleri şeklinde tanımlamaktadır. Epistemolojinin temel soruları ve bu sorulara ilişkin çeşitli önermeleri bulunmaktadır (Topdemir, 2011; Sönmez, 2010; Kale, 2009; Sözer, 2009; Bochenski, 2009; Hofer ve Pintrich, 2002). Bu önermeler, genelde bilginin sınırı, kesinliği, doğruluğu, gelişimi ve değişimi başlıkları altında incelenebilir. Bu önermelerden Hofer ve Pintrich' in (1997) epistemolojinin alanları, boyutları ve tanımlamalarına ilişkin önermeleri Tablo 1'de sunulmuştur.

Tablo 1. Hofer ve Pintrich'e (1997) göre epistemolojik inancın alanlarl, boyutlart ve tanimlart

\begin{tabular}{|c|c|c|c|}
\hline & $\begin{array}{c}\text { Genel } \\
\text { alanlar }\end{array}$ & Alt boyutlar & Tanım \\
\hline \multirow{3}{*}{ 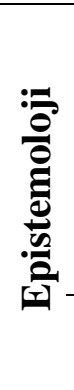 } & \multirow[b]{2}{*}{$\begin{array}{l}\text { Bilmenin } \\
\text { doğası }\end{array}$} & $\begin{array}{l}\text { Bilginin } \\
\text { kaynağ } 1\end{array}$ & $\begin{array}{l}\text { Bilgi dışarıdaki bir otorite tarafindan belirlenir (Dogmatik) } \\
\text { Bilgi bilen tarafından yapılandırılır (Skeptik) }\end{array}$ \\
\hline & & $\begin{array}{l}\text { Bilginin } \\
\text { doğrulanması }\end{array}$ & $\begin{array}{l}\text { Bilgi doğrulanmaya gerek duyulmadan başkalarının } \\
\text { belirlediği gibi kabul edilir (Dogmatik) } \\
\text { Bilgi, uzmanlarının kanıtları ve değerlendirmeleri üzerine } \\
\text { kurulur (Skeptik) }\end{array}$ \\
\hline & $\begin{array}{l}\text { Bilginin } \\
\text { doğas } 1\end{array}$ & $\begin{array}{l}\text { Bilginin } \\
\text { gelişimi }\end{array}$ & $\begin{array}{l}\text { Değişmeyen ve sabit bilginin doğası (Dogmatik) } \\
\text { Gelişen ve değişen bilginin doğası (Skeptik) }\end{array}$ \\
\hline
\end{tabular}


http://dx.doi.org/10.23891/efdyyu.2017.9

ISSN:1305-020

$\begin{array}{ll}\text { Bilginin } & \text { Tek bir doğru (Dogmatik) } \\ \text { kesinliği } & \text { Birden fazla doğru (Skeptik) }\end{array}$

Tablo 1' de görüldüğ̈̈ gibi Hofer ve Pintrich (1997) epistemolojinin alanlarını, bilmenin doğası ve bilginin doğası boyutları ile incelemektedir. Bu alt boyutlar, bilginin ve bilme eyleminin genel olarak dışa bağımlı, otorite ve sorgulamadan bağımsız gelişimi için dogmatik, bireysel yapılandırma, otoriteden bağımsız ve sorgulamaya dayalı gelişimi için de skeptik (şüpheci/kuşkucu) felsefi düşünme eğilimini önermektedir. Perry (1981) ise epistemolojik görüşlerde kesin/değişmez bilgiden, değişebilen/kesin olmayan bilgiye doğru bir geçiş olduğunu belirtmektedir.

Çocukların yaratıcı düşünceye ait potansiyelleri ve kapasiteleri (Torrance, 1972), öğrenmeyi başlatan merakları (Tuğrul, Güneş, Tokuç ve Boz, 2012), sosyal ilişkilerde ve matematiksel sorunlardaki problem çözme becerileri (Akman, 2002; Joseph ve Strain, 2010), hepsinin birer fillozof olduğunu gösteren kanıtlar olarak kabul edilebilir. Çocuklarda epistemolojik görüşlerin çok erken yaşlardan itibaren geliştiği çeşitli araştırmalarla da ortaya konmuştur (Collins ve Princh, 1993; Schommer, 1990; Yang ve Tsai, 2010). Yang ve Tsai (2010) çocukların fikir yürütecekleri konularla ilgili duygularının, hislerinin ve geliştirdikleri bazı stratejilerin de bireysel epistemolojik inançlarını etkilediğini belirtmiştir. $\mathrm{Bu}$ araştırmalardan farklı olarak Burr ve Hofer (2002) epistemolojik görüşlerin çok daha küçük yaşlarda gelişmeye başladığı, her ne kadar o dönemdeki epistemolojik inançlar benmerkezci bir yapıda da olsa, bilginin sınırına, kaynağına ve akıl yürütmeye ilişkin ilk görüşlerin kazanıldığını açıklamaktadır. Bunun yanı sıra, yaş büyüdükçe epistemolojik görüşlerin de daha fazla olgunlaştığı ve geliştiği bilinmektedir (Kuhn, 1991; Weinstock, Neuman ve Glassner, 2006).

Son yıllarda okul öncesi eğitimi alanında yapılan çalışmalar incelendiğinde genelde 
http://dx.doi.org/10.23891/efdyyu.2017.9

ISSN:1305-020

çocukların gelişimleri ve öğrenmeleri üzerine uygulanan yöntem ve tekniklerin etkililiğini içeren çalışmalara rastlanmakta fakat tüm bu çalışmaların temeli olan "bilginin kökenine" ilişkin yeterli araştırma olmadığı düşünülmektedir. $\mathrm{Bu}$ bağlamda, okul öncesi dönem çocuklarının felsefi düşüncelerinin epistemoloji bağlamında incelenmesinin ilgili alan yazım için önemli olduğu düşünülmektedir.

\section{Yöntem}

Araştırmanın Deseni: Araştırmanın deseni nicel, yöntemi ise betimsel nitelikli tarama modelidir. Karasar (2013) betimsel nitelikli tarama modelini en genel hali ile ilgilenilen bir durumu tanımlayarak (betimsel araştırma), var olan bu durumu var olduğu biçimde ve nesnel bir yaklaşımla ortaya koyma çabası (tarama modeli) olarak belirtmektedir.

Çalışma Grubu: Araştırma, 2015-2016 akademik yılında Ankara ilinde bulunan ve MEB' e bağlı 3 devlet anaokuluna devam eden 73 kız ve 68 erkek olmak üzere toplam 141 çocukla yürütülmüştür. Araştırmanın konusu olmamasına rağmen tek yönlü sonuçlardan kaçınma amacı ile örneklem alt, orta ve üst SED’ i dengeli sayılabilecek şekilde temsil eden gruplardan seçilmiştir. Çalışma grubunun \%33' i alt, \%36' u orta ve \%31' si ise üst SED' dendir. SED' in değişken olarak belirlenmesinde anne/baba eğitim durumu (alt SED: ilköğretim, orta SED: lise, üst SED lisans düzeyleri), anne/baba gelir durumu (alt SED: asgari ücret, orta SED: 2000TL-3500TL, üst SED: 3500TL ve üzeri), okulun konumu (alt SED ve orta SED: uzak yerleşke alanları ve üst SED: merkezi yerleşkelere yakınlığı) SED belirleyicileri olarak değerlendirilmiştir.

Veri Toplama Araçları: Veri toplama aracı olarak; Epistemolojik Etkinlikler Seti (EES) ve Çocuklar İçin Epistemolojik Görüş Ölçeği (ÇİEGÖ) kullanılmıştır. 
http://dx.doi.org/10.23891/efdyyu.2017.9

ISSN:1305-020

EES: EES; çocukların epistemolojik görüşlerinin belirlenebilmesi için Güneş (2014) tarafından geliştirilen, sorgulamaya dayalı "Dinozorların Sırrı”, uygulamaya dayalı "Su - ataç Deneyi" ve sonu çocuklar tarafından tamamlanması istenen "Bilgiç Baykuş - Akıllı Kedi Hikâyesi” isimli etkinliklerden oluşmaktadır. Dinozorların, çocuklar için merak uyandıran ve son yı1larda popülaritesi artan konulardan olması, çocukların bilim müzelerinde/merkezlerinde gösterdikleri yoğun ilgi (Stemmler, 2006) ve bunun yanı sira bu konuda çocuklarla yapılan araştırmalardan (Johnson, Scott ve Mervis, 2004) dolayı etkinlik setinde dinozorlarla ilgili diyaloğa yer verilmiştir. Su-ataç deneyi, Toulmin’ in (1990) argümantasyon tekniği olarak tanımladığı, veri, gerekçe, destek ve çürütmeleri kullanarak ikna etme süreçlerinden faydalanarak hazırlanmıştır. Bilgiç Baykuş - Akıllı Kedi hikâyesi ise White' in (2010) kitabında yer alan ve iki filozofun arasında geçen diyalogdan esinlenerek çocuklara fabl türünde okunmuştur. İki filozof arasında geçen hikâyede, filozoflardan biri diğerine "hiç kimsenin olmadığı bir ormanda ağaç devrilse ses duyar mıyız?" şeklinde bir soru yöneltmektedir. Berkeley bu soruya "bilinmez" cevabını vererek, "evet" ve "hayır" cevaplarına bir üçüncüsünü ekleyerek skeptik bir yaklaşım sergilemiştir. Çocuklarla yapılan hikâye tamamlama etkinliği ise, çocukların duygu ve düşüncelerini daha rahat ifade edebildikleri bir teknik olmasından dolayı etkinliğin bu şekilde uygulanmasına karar verilmiştir. Her üç etkinlikte yer alan maddeler bilmenin ve bilginin doğasına yönelik hazırlanmıştır. Etkinliklerin her biri toplam 10 maddeden oluşan bir yapıda hazırlanmıştır (alt boyutlar ve soruların ait oldukları alt boyutların gösterimi Şekil 1' de sunulmuştur). Etkinlikleri oluşturan alt boyutlar EES' in tümü için ortaktır.

EES' in kapsam geçerlilik çalışmaları kapsamında Davis Tekniğinden (1992) yararlanılmış ve 10 uzman görüşü üzerinden ESS maddelerinin Kapsam Geçerlilik İndeks 
http://dx.doi.org/10.23891/efdyyu.2017.9

ISSN:1305-020

(KGI) değerlerinin 0.8 ile 1.00 arası değişen değerlerde olduğu hesaplanmıştır. EES' in ilk

pilot uygulaması 15, ikinci pilot uygulaması ise 10 çocukla yapılarak ESS' in nihai formuna ulaşılmıştır.

EES' i oluşturan, Dinozorların Sırrı, Su - ataç Deneyi ve Bilgiç Baykuş - Akıllı Kedi Hikayesi etkinliklerinin puan hesapları aynı metodoloji ile yapılmıştır. Değerlendirme sürecinin standart olabilmesi için ortak bir rubrik hazırlanmış ve çocukların yanıtları bu rubriklere göre değerlendirilmiştir. Araştırmaya katılan çocuklardan birinin Dinozorların Sırrı isimli etkinliğe verdiği yanıtların rubrik üzerindeki gösterimi ve aldığı puan örnek olarak Şekil 1' de sunulmuştur.

\begin{tabular}{|c|c|c|c|c|c|c|c|c|c|c|c|c|c|}
\hline \multirow[t]{2}{*}{ Madde } & \multirow[t]{2}{*}{ Yanitlar } & \multirow[t]{2}{*}{$\square$} & \multirow[t]{2}{*}{$\Delta$} & \multirow[t]{2}{*}{ 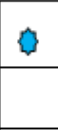 } & \multirow[t]{2}{*}{ Puan } & \multirow[t]{2}{*}{ Madde } & \multirow[b]{2}{*}{$\begin{array}{l}\text { Bilginin } \\
\text { doğası }\end{array}$} & \multirow[t]{2}{*}{\begin{tabular}{|c|} 
Epistemolojik \\
görüș alt boyutları
\end{tabular}} & \multicolumn{3}{|c|}{ Yanitlar } & \multirow[b]{2}{*}{ Simgeleme } & \multirow[b]{2}{*}{ Değerler } \\
\hline & & & & & & & & & $\square$ & $\Delta$ & 方 & & \\
\hline 1 & $\begin{array}{l}\text { Çizgi filmlerden } \\
\text { öğrendim }\end{array}$ & 0 & $\bullet$ & 0 & 2 & 8 & & $\begin{array}{l}\text { Bilginin } \\
\text { olanağı }\end{array}$ & 0 & $\bullet$ & 0 & & \\
\hline 2 & $\begin{array}{l}\text { Sirtlarinda } \\
\text { dikenleri var }\end{array}$ & 0 & 0 & $\boldsymbol{0}$ & 3 & 7 & & $\begin{array}{l}\text { Bilginin } \\
\text { kesinliği }\end{array}$ & $\bullet$ & 0 & $\mathrm{O}$ & $\square 1$ puan & Bilgi yok \\
\hline 3 & $\begin{array}{l}\text { Ögrretmenime } \\
\text { sorarım }\end{array}$ & 0 & $\bullet$ & 0 & 2 & 10 & & $\begin{array}{l}\text { Bilginin } \\
\text { kesinliği }\end{array}$ & 0 & 0 & $\bullet$ & $\Delta 2$ puan & $\begin{array}{l}\text { Dogmatik } \\
\text { düșünce }\end{array}$ \\
\hline 4 & Evet, doğrudur & 0 & $\bullet$ & 0 & 2 & 9 & & $\begin{array}{l}\text { Bilginin } \\
\text { gelișimi }\end{array}$ & 0 & $\bullet$ & 0 & \{\}$^{3}$ puan & $\begin{array}{l}\text { Skeptik } \\
\text { düșünce }\end{array}$ \\
\hline 5 & Mucitler & 0 & $\bullet$ & 0 & 2 & 6 & & $\begin{array}{l}\text { Bilginin } \\
\text { sinurlar1 }\end{array}$ & 0 & $\bullet$ & 0 & & \\
\hline 6 & \begin{tabular}{|l|}
$\begin{array}{l}\text { Her șeyi } \\
\text { biliyorlar }\end{array}$ \\
\end{tabular} & 0 & - & 0 & 2 & & $\begin{array}{l}\text { Bilmenin } \\
\text { doğası }\end{array}$ & & & & & & \\
\hline 7 & Bilmiyorum & - & 0 & 0 & 1 & 1 & & \begin{tabular}{|l|} 
Bilginin \\
kaynağı
\end{tabular} & 0 & $\bullet$ & 0 & & \\
\hline 8 & $\begin{array}{l}\text { Görmedim ama } \\
\text { öldüklerini } \\
\text { düșünüyorum }\end{array}$ & 0 & $\boldsymbol{0}$ & 0 & 2 & 5 & & Otorite & 0 & 0 & 0 & $\square 1$ puan & Bilgi yok \\
\hline 9 & \begin{tabular}{|l|} 
Dinozorlarla \\
ilgili \\
öğreneceğimiz \\
yeni șeyler bitti
\end{tabular} & 0 & - & 0 & 2 & 2 & & $\begin{array}{l}\text { Akal yürütme } \\
\text { süreci }\end{array}$ & 0 & 0 & $\bullet$ & 2 puan & $\begin{array}{l}\text { Dogmatik } \\
\text { düșünce }\end{array}$ \\
\hline 10 & $\begin{array}{l}\text { Değișebilir, } \\
\text { belki yeni } \\
\text { șeyler } \\
\text { öğrenebiliriz }\end{array}$ & 0 & 0 & $\bullet$ & 3 & 3 & & $\begin{array}{l}\text { Bilgi üretme } \\
\text { süreci }\end{array}$ & 0 & • & 0 & ${ }^{3}$ puan & $\begin{array}{l}\text { Skeptik } \\
\text { düșünce }\end{array}$ \\
\hline Toplam & & 1 & 7 & 2 & & 4 & & Bilginin kesinliği & 0 & 0 & 0 & & \\
\hline Puan & & $1 * 1$ & $7 * 2$ & $2 * 3$ & 21 & Puan & & & $1 * 1$ & $7 * 2$ & $2 * 3$ & $\begin{array}{c}1+14+6=21 \\
21 / 10=2.1\end{array}$ & $\begin{array}{l}\text { Dogmatik } \\
\text { düșünce }\end{array}$ \\
\hline
\end{tabular}

Şekil 1. Bir çocuğun dinozorların sırrı etkinliği yanıt anahtarı

Şekil 1' de görüldüğü gibi uygulanan etkinlik sonucunda bu yanıtları veren çocuğun toplam 21 puan aldığı ve bu puanın dogmatik düşünce sınırlarında kaldığı söylenebilir. 
http://dx.doi.org/10.23891/efdyyu.2017.9

ISSN:1305-020

Yanıtlar incelendiğinde bilginin kaynağı olarak çizgi filmi, bilgi üretme sürecinde ise öğretmeni araç olarak görmekte buna karşın akıl yürütme alt boyutunda ise dinozorların diğer hayvanlardan farklı olan bir özelliğini fark ederek karşılaştırma yapabildiği görülmektedir.

Dış kaynaklı ve otoriteye bağlı yanıtlara 2, nedensel-karşılaştırmalı ve bireysel yapılandırma süreçleri ile otoriteden bağımsız düşünme eğilimlerini yansıtan yanıtlara 3, bilmiyorum yanıtlarına ise 1 puan verilmiştir.

EES Uygulama: ESS' in içinde yer alan 3 etkinlikte çocuklarla bireysel olarak uygulanmıştır. Dinozorların Sırrı etkinliğinin 10 dakika, Su-ataç deneyinin 10-15 dakika ve Bilgiç Baykuş - Akıllı Kedi Hikâyesi içinse 10 dakika ortalama uygulama süresi olduğu tespit edilmiştir. Çalışmaya katılan çocukların özellikleri, motivasyonları ve dikkat süreleri göz önüne alınarak EES' in uygulanması 2 güne yayılmıştır.

ÇiEGÖ: ÇİEGÖ’ nün felsefi temelleri, Elder (2002) tarafından geliştirilip Acat, Tüken ve Karadağ' in (2010) Türkçe' ye uyarladığı Bilimsel Epistemolojik İnanç Ölçeğine (BEİÖ) dayanmaktadır. Güneş (2014) tarafından geliştirilen ÇİEGÖ, uygulamaya dayalı otorite/doğruluk, bilgi üretme süreci, bilginin değişimi, akıl yürütme ve bilginin değişimi olmak üzere 5 alt boyuttan oluşmakta ve 25 madde içermektedir. ÇíEGÖ 3' lü likert tipte hazırlanmıştır ve bu araştırmada cronbach alpha değeri .798 olarak hesaplanmıştır.

ÇİEGÖ’ nün geliştirilme aşamasında yapılan geçerlilik-güvenirlik çalışmalarında cronbach alpha değeri 922 olarak hesaplanmıştır. Kapsam geçerliliği için 14 uzmandan görüş alınarak uygulanan Davis Tekniği (1992) sonuçlarına göre maddelerin KGİ' lerinin 0.79 ile 1.00 arasında değişim gösterdiği rapor edilmiştir. Bunun yanı sıra, güvenirlik çalışmaları kapsamında yapılan madde analizleri ile geçerlilik çalışmaları kapsamında yapılan faktör analizlerine göre ÇİEGÖ’ de yer alan maddelerin ölçekle istatistiksel olarak anlamlı, uyumlu 
http://dx.doi.org/10.23891/efdyyu.2017.9

ISSN:1305-020

ve ölçeğe güçlü şekilde katkı sağlayan maddeler olduğu belirtilmiştir (Güneş, 2014). Çi̇EGÖ maddeleri, çocukların daha kolay anlayabilmeleri için tek bir yargı ya da cümle olarak değil uygulamalı ve kurgusal/senaryolara uygun olarak geliştirilmiştir.

ÇİEGÖ’ den örnek maddeler aşağıdaki verilmiştir. Yanıtların değerlendirilmesinde Hofer ve Pintrich' in (1997) epistemoloji sorularına karşı geliştirdikleri önermelerden faydalanılmıştır. ÇİEGÖ’ nün kodlanmasında ve puanlanmasında, EES’ de kullanılan rubrik ve puanlama mantığından yararlanılmıştır.

Madde 1. Hangisi yüzer, hangisi batar (taş ve tahta)? Peki neden? [deneyerek bulma ve akıl yürütme: skeptik (3 puan); direk yanıt söyleme ve dogmatik argümanlar (öğretmen, anne-baba söyledi, çizgi filmlerde gördüm) dogmatik (2 puan), bilmiyorum (1 puan)]

Madde 5. Sence öğretmenin her şeyi biliyor mudur? Bilmediği şeyler de var mıdır? [her şeyi bilemeyebilir: skeptik ( 3 puan); her şeyi bilir: dogmatik ( 2 puan); bilmiyorum: bilgi oluşmamış (1 puan)].

Madde 16. Sence tüm çocuklar anne/babalarının ve öğretmenlerinin söylediği her şeye inanmalı mıdır? [hepsine inanmamalıyız: skeptik (3 puan); hepsine inanmalıyı: dogmatik (2 puan); bilmiyorum: bilgi oluşmamış (1 puan)].

ÇiEGÖ Uygulama: ÇİEGÖ’ nün uygulama süresi ortalama olarak 15-20 dakika arasında değişmektedir. Bu süre, çocukların bireysel farklılıklarına bağlı olarak, değişiklik gösterebilmektedir.

Verilerin Analizi: EES ve ÇİEGÖ elde edilen sonuçlar Tekin’ in (1993) ölçek aralık formülü (dizi genişliği/yapılacak grup sayısı [2/3 0.66]) kullanılarak sunulmuştur. Buna göre, EES ve ÇİEGÖ' deki aralık değerleri: "Bilgi yok - kavramsal bilgi oluşmamış” için 1.00-1.66 
http://dx.doi.org/10.23891/efdyyu.2017.9

puan aralığ1; "dogmatik felsefi düşünce" için 1.67-2.33 ve "skeptik felsefi düşünce" için ise 2.34-3.00 puan aralığ ş̧eklinde belirlenmiştir.

\section{Bulgular}

EES' den bazı soruların yanıtları örnek olarak sunulmuştur.

Epistemolojik Etkinlikler Seti - "Dinozorların Sırrı Diyaloğu”

A: araştırmacı, Ç1: Orta SED 5 yaş grubundan erkek çocuk

A: Peki, sen bunun dinozor olduğunu nereden biliyorsun, nasıl öğrendin? (Bilginin kaynağı)

Ç1: Tireks bu, bu dinozorun çizgi filmi vardl. (Dogmatik: 2 puan)

A: Peki sen bunun dinozor olduğunu nasıl anladın?(Akıl yürütme)

Ç1: Dinozorların sırtında böyle dikenler olur, başka hayvanların olmaz ki (Skeptik: 3 puan)

Epistemolojik Etkinlikler Seti - "Su-ataç Deneyi”

A: araştırmac1, Ç2: Orta SED 5 yaş grubundan kız çocuk

A: Şimdi seninle bir su deneyi yapacağız. Bakalım beğenecek misin? Deneye geçmeden önce sana küçük bir sorum olacak. Sence bu ataçlar, suda yüzer mi batar mı? Yüzüp yüzemeyeceğini bilebilir miyiz? (Bilginin olană̆l)

Ç2: Bence yüzmez. Demir ya ondan batar, sadece tahtalar yüzer, bir de gemiler, öğretmenim öyle demişti (Dogmatik: 2puan)

A: Sence bunu nasıl anlarız? (Bilgi üretme süreci)

Ç2: Deneriz. (Skeptik: 3 puan)

A: Peki, bir de ben denemek istiyorum, belki de ataçlar yüzüyordur. (Araştırmacı, atacı suya bırakır ve ataçlar suyun yüzey geriliminden dolayı yüzer). Bak şimdi de ataçlar yüzüyor...

Ç2: Aaaa, Nasıl oldu? Ne yaptın? Bende yapacă̆ım. (Ataçları, araştırmacının suya bıraktı̆̆ 
http://dx.doi.org/10.23891/efdyyu.2017.9

ISSN:1305-020

gibi suya bırakmaya çalışır, 4. denemede yüzdürmeyi başarır)

A: Az önce ataçların batacağını söylüyordun ama şimdi yüzdüğünü gördün. (Bilginin değişimi)

Ç2: Değişti, yani batanlar da var işte.. Ama yüzenlerde var...(Skeptik: 3 puan)

Epistemolojik Etkinlikler Seti - "Bilgiç Baykuş-Akı1lı Kedi Hikâyesi”

A: araştırmacı, Ç3: Alt SED 6 yaş grubundan klz çocuk

A: Peki, sence bizim hikâyenin gerçek cevabını öğrenebilir miyiz? (Bilginin olană̆ı)

Ç3: bilmiyorum ben. (Kavramsal bilgi oluşmamış: 1 puan)

A: Sence ne yaparsak doğru/gerçek cevabı ögrenebiliriz? (Bilginin üretme süreci)

Ç3: Öğretmene soralım, o bilir bence. (Dogmatik : 2 puan)

A: Bu hikâyedeki sorunun cevabını: hangisinden öğrenmeyi istersin? (Bilginin kaynă̆l)

Ç3: Öğretmenden, onlar her şeyi biliyorlar (Dogmatik: 2 puan)

Çocukların ilk felsefi görüşlerinin ben merkezci felsefi düşünceler olarak geliştiği aşağıdaki örneklerde de görülmektedir.

5 yaş grubundan bir çocuk: ben ağacın yanında olsaydım sesini duysaydım anlardım

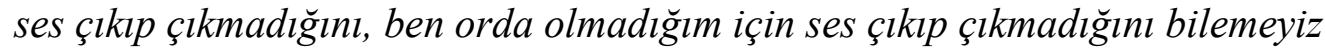

5 yaş grubundan başka bir çocuk: bence dinozorlar yaşlyordur, çünkü ben yaşamalarını çok istiyorum

EES' de yer alan soruları, çocukların birden fazla seçenek belirterek yanıtlamalarından dolayı, ulaşılan bazı değerlerin oranları 100' ü aşmaktadır. Çocuklarda genel olarak otorite figürünün öğretmen, bilim insanı ve ebeveynler olarak yerleştiği, öğretmenlerin otorite figürler içindeki oranının $\% 78$, bilim insanlarının oranın $\% 67$ ve ebeveynlerin ise $\% 63$ olduğu tespit edilmiştir. Bilginin değişimi konusunda çocukların \%39’ u bilginin değişebileceğine 
http://dx.doi.org/10.23891/efdyyu.2017.9

ISSN:1305-020

inandıkları, \%47' sinin değişmeyen sabit bilgiye inandıkları ve \%24' ününde bu konuda görüşünün olmadığı sonucuna ulaşılmıştır. Akıl yürütme alt boyutunda, çocukların \%53’ü problemlere karşı analitik, nedensel ve karşılaştırmalı akıl yürütme stratejilerini kullanabildiklerini göstermiştir. Çocuklar büyük oranda (\%87) bilginin olanağına inanmaktadır ve var olan bilgilerin kaynağı olarak öğretmenlerini, bilim insanlarını, ebeveynlerini, kitapları ya da belgeselleri görmektedirler. Bilginin kaynağı ve ulaşma yollarında empirik yaklaşım (araştırmacı tarafından "deneyelim”, "araştıralım” gibi yanıtlar empirik yaklaşım olarak kabul edilmiştir) sergileyen çocukların oranı ise \%46 olarak hesaplanmıştır. EES sonuçlarına göre çocukların, bilginin varlığına ve bilginin doğruluğuna yönelik güçlü dogmatik görüşleri olduğu söylenebilir. Bunun yanı sıra bilgi üretme süreçlerinde daha bireysel ve deneme yaparak bilgiye ulaşma eğilimi gösterdikleri söylenebilir.

ÇİEGÖ’ ye ilişkin bulgular

Çocuklara uygulanan ÇİEGÖ’ye ilişkin betimsel istatistik sonuçları Tablo 2' de sunulmuştur.

Tablo 2. ÇİEGÖ betimsel istatistik ve ölçek değer aralıkları sonuçları

\begin{tabular}{lrrrrrl}
\hline \multicolumn{1}{c}{ Alt boyut } & Min. & \multicolumn{1}{c}{ Max. } & SS & \multicolumn{1}{c}{ S } & \multicolumn{1}{c}{$\overline{\mathbf{X}}$} & \multicolumn{1}{c}{ Ölçek Değer Aralığı } \\
\hline Otorite/Doğruluk & 7.00 & 21.00 & 2.64 & 7.21 & 15.95 & $2.28=$ Dogmatik Düşünce \\
Bilgi Üretme Süreci & 7.00 & 21.00 & 3.23 & 9.71 & 15.47 & $2.41=$ Dogmatik Düşünce \\
Bilginin Kaynağı & 5.00 & 15.00 & 2.21 & 4.67 & 10.50 & $2.10=$ Dogmatik Düşünce \\
Akıl Yürütme & 3.00 & 9.00 & 1.37 & 1.87 & 7.20 & $2.40=$ Skeptik Düşünce \\
Bilginin Değişimi & 3.00 & 9.00 & 1.34 & 1.84 & 7.46 & $2.49=$ Skeptik Düşünce \\
Bütün ÇİEGÖ & 28.00 & 75.00 & 8.69 & 75.94 & 56.58 & $2.26=$ Dogmatik Düşünce \\
\hline
\end{tabular}

Tablo 2' de çocukların epistemolojik görüşlerinin genel olarak dogmatik felsefi düşünce alt sınırları içinde olduğu görülmektedir. Ölçek değer aralığında dogmatik felsefi düşünce ile skeptik-şüpheci/kuşkucu felsefi düşünce sınırı 2.33 olarak belirlenmiştir. Bu yönü ile ölçek 
http://dx.doi.org/10.23891/efdyyu.2017.9

ISSN:1305-020

değerleri 2.26 olan okul öncesi çocuklarının dogmatik felsefi düşünme sınırı içinde kaldığ1 görülmektedir. Öte yandan akıl yürütme ve bilginin değişimi alt boyutlarında çocukların skeptik-şüpheci/kuşkucu felsefi düşüncenin önermelerine yaklaştıkları söylenebilir. Genel olarak, çocukların öğrenmelerinde bilgi üretme süreci ve problemlere karşı dış kaynaklı çözümleri tercih ettikleri görülmektedir.

\section{Tartışma ve Sonuç}

Araştırmada okul öncesi dönem çocuklarının epistemolojik görüşlerinin belirlenmesi amaçlanmıştır. Araştırmada elde edilen bulgulara göre, genel olarak çocukların çoğunlukla dogmatik felsefi düşünme eğiliminde oldukları belirlenmiştir. Çocukların dogmatik yaklaşımlarında öğretmenlerine duydukları koşulsuz bağlılık, otoriteye karşı gösterdikleri itaati açıklamaktadır ve otoriteye bağlılık dogmatik bir yaklaşım şeklidir. Çocuklar için öğretmenlerin söylediği her şey, öğrettikleri tüm bilgiler tartışmasız doğrudur. Çünkü onlara göre zaten o bilgileri öğretmenler söylemiştir ve öğretmenler yanlış bir şeyler söylemez ya da öğretmez. Araştırmaya katılan çocukların bu düşünceleri, Anderson (1984) ve Clark' ın (1998) belirttiği gibi çocukların epistemolojik inanç sistemleri üzerinde öğretmenlerin epistemolojik inanç sistemlerinin oynadığı rolün göstergesi olarak yorumlanabilir. Eğitimcilerin çocukların epistemolojik görüşlerinin gelişmesindeki etkisi ile ilgili olarak Hofer (2001) ve Schraw (2001) çocukların epistemolojik inançlarının değişimi ve şekillenmesinde öğretmenlerin rollerine vurgu yapmaktadır.

Araştırmaya katılan birçok çocuk için şuanda olmayan bir şeyin bilgisine de ulaşmak mümkün değildir. Çoğu çocuk için geçmişte olan bir şey (araştırmanın etkinliklerinde dinozorlar ve onlara ilgili tüm bilgiler) geçmişte kalmıştır ve bizlerin geçmişe gidip bu bilgileri araştırmamız ve öğrenmemiz, onları değiştirmemiz imkânsıza yakındır. Öte yandan 
http://dx.doi.org/10.23891/efdyyu.2017.9

ISSN:1305-020

çocuklara göre, bilim insanlarının ve öğretmenlerin öğrettiği şeyler kesin ve değişmez doğrulardır. Bunun yanı sıra, araştırmada yer alan çoğu çocuk için bir bilginin değişimi, çocuğun otorite figür olarak gördüğü kişi ya da araçlar tarafindan mümkündür. Çalışmada yer alan çocuklara ait bu ifadeler, Anderson’ in (1984) çocuklar için öğretmenlerinin, ailelerinden sonra en etkili deneyim rehberi ve bilgi konusunda otorite figürü olduğu tespiti ile Schommer' In (1993) öğretmenlerin bazen farkına varmadan çocukların epistemolojik görüşlerini olumsuz yönde etkileyebildikleri görüşü çerçevesinde değerlendirilebilir.

Epistemolojinin alt boyutlarından olan, otoriteye bağlılık, bilginin kaynağı ve bilgi üretme süreçlerinde çocukların genel olarak dogmatik görüşleri benimsemesine rağmen bir kısmının empirik (deneyci) yaklaşımlarla skeptik felsefi düşüncenin önermelerine yaklaştıkları söylenebilir. Çocukların deneyci yaklaşımları bilgiye ulaşma için gösterdikleri çabaya işaret etmektedir. Bu çabanın çocukların epistemolojik görüşlerinin gelişimi için değerli olduğu düşünülmektedir (Başbay, 2013). Bununla birlikte, akıl yürütme ve bilginin değişimi alt boyutlarında yer alan problemlere karşı da skeptik görüşlere sahip oldukları tespit edilmiştir. Çocukların otorite figürlere olan bağlılığı sadece öğrenmelerinde değil aynı zamanda bedensel, zihinsel ve sosyal gelişimlerinde belirleyici bir etkiye sahip olan oyunlarında bile görülmektedir. Benzer bir bulgu Güneş, Öz ve Tuğrul (2012) tarafından çocukların oyun kurallarına uyma ve oyun kurallarını korumada otoriteye karşı büyük bir bağlılık gösterdikleri şeklinde rapor edilmiştir. Buradan hareketle çocukların dogmatik düşünce eğilimlerinin temelinde, yaşamlarını şekillendiren öğrenme etkinliklerinden oyunlarına kadar, birçok deneyimlerinde otorite figürlere karşı gösterdikleri bağlılık olduğu söylenebilir. 
http://dx.doi.org/10.23891/efdyyu.2017.9

ISSN:1305-020

Araştırmaya katılan çocukların epistemolojik görüşlerinde sergiledikleri benmerkezci eğilim Burr ve Hofer' in (2002) ilk epistemolojik görüşlerin, çocukların benmerkezci oldukları dönemin etkisinde daha öznel bir yapıda gelişmeye başladığı tespiti ile örtüşmektedir. Bazı yanıtların oldukça bireysel ve çocuğun o anki duyguları ile şekillenmesi Louca, Elby, Hammer ve Kagey’ in (2004) belirttiği gibi çocuklardaki duygu ve hislerin epistemolojik görüşlerine ve epistemolojik görüşlerinin gelişimine olan etkisi ile açıklanabilir. Bunun yanı sıra çocukların günlük rutinleri ve etkileşime girdikleri sosyal çevresinden edindikleri kazanımlarının epistemolojik etkinliklere verdikleri yanıtları şekillendirdiği görülmektedir. Örneğin izledikleri çizgi filmdeki dinozor karakteri çocukların dinozorlarla ilgili eksik-yanlış veya tutarsız bilgilerinin oluşumuna neden olmakta ve geliştirdikleri epistemolojik görüşlerde de bu durum açıkça ortaya çıkmaktadır. Bu bağlamda, çocukların etkileşim halinde oldukları yakın sosyal öğrenme alanı (aile-okul-arkadaş ve öğretmen), epistemolojik görüşlerin gelişiminde belirleyici bir rol oynamakla birlikte bazı zamanlarda da olumsuz/yetersiz bilgi görüşlerine/inançlarına ve değerlerine zemin oluşturabilmektedir. $\mathrm{Bu}$ yorumu Johnston, Woodside-Jiron ve Day’ ın (2001) çocukların çevrelerinden davranış rutinleri, inançlar, değerler, roller ve kimlikler edindikleri ve bunların uzun vadede problemlere dönüşebileceği görüşü desteklemektedir.

Epistemolojik modellemelerden elde edilen bulguların, Perry' nin ve sonrasında bilgiye ilişkin farklı yaklaşımları temel alan Kuhn' un (1991), Baxter Magolda' nın (1992) ve King ve Kitchener' in (1994) epistemolojik modelleri ile paralel bir yapı sergilediği söylenebilir. Bilginin barındırdığı unsurlar ve epistemolojik görüşlerin/inançların gelişimselliğinin incelendiği bu araştırmalarda genel olarak bireylerin yaşa bağlı olarak epistemolojik görüşlerinin daha esnek, değişebilen ve sorgulamaya dayalı bir anlayışa kaydığı 
http://dx.doi.org/10.23891/efdyyu.2017.9

ISSN:1305-020

rapor edilmiştir. Araştırmada geliştirilen modelde ise bilginin kaynağı, değişimi ve akıl yürütme süreçleri temel alınarak, ortaya konan problemlere karşı geliştirilen argümanların hangi felsefi önermeleri içerdiği incelenerek bu önermelerin oluşturduğu felsefi düşünme alanları belirlenmeye çalışılmıştır. Modellerde ulaşılan sonuçlar, test ölçümleri ile belirlenmesi zor olan kayıp alanları, bu alanların hangi alt boyutlarda ortaya çıktığı ve birbiri ile olan ilişkisini açıklamaktadır.

Araştırmanın sonuçlarına göre çocuklarının epistemolojik görüşlerinin dogmatik felsefi düşünce sınırında olması ile birlikte skeptik felsefi düşünceye de yaklaştıkları söylenebilir. Çocukların ölçeğin tümü üzerinde aldıkları toplam puanın 58.58, ölçek değer aralığında ise 2.26 ile dogmatik felsefi düşünme alanına doğru eğilim gösterdiği görülmektedir.

\section{Öneriler}

Yeni araştırmalarda, epistemolojik görüşlerle ilgili çalışmalar okul öncesi dönem grupları ile boylamsal çalışmalar şeklinde sürdürülebilir. Epistemolojik görüşlerin oluşumu ve gelişiminde etkisi olabilecek değişkenler belirlenip, yapılacak boylamsal çalışmalarda etki düzeyleri tespit edilmeye çalışılabilir. Ayrıca epistemoloji alanında geliştirilecek matematiksel modellemeler yardımı ile epistemolojik görüş modellemelerine ulaşılabilir ayrıca zaman içinde elde edilen modellemelerdeki değişimler analitik olarak incelenebilir.

\section{Makalenin Bilimdeki Konumu (Yeri)}

İlköğretim Bölümü/ Okul Öncesi Eğitimi Anabilim Dalı

\section{Makalenin Bilimdeki Özgünlüğü}

Çocuklarla felsefe çalışmalarında uygulanabilecek uygulamalara dayalı etkinlik seti ile epistemolojik görüş ölçeğinin ilgili alan yazıma katkı sağlayacağı düşünülmektedir. 


\section{Kaynaklar}

Acat, M. B., Tüken, G., ve Karadağ, E. (2010). Bilimsel epistemolojik inançlar ölçeği: Türk kültürüne uyarlama, dil geçerliği ve faktör yapısının incelenmesi. Türk Fen Ĕ̆gitim Dergisi, 7(4), 67-89.

Akman, B. (2002). Okul öncesi dönemde matematik. Hacettepe Üniversitesi Eğitim Fakültesi Dergisi, 23, 244-248.

Anderson, R. (1984). Some reflections on the acquisition of knowledge. Educational Researcher, 5-10.

Aristotle (2004). Metaphysics. (Çev. Lawson-Tancred, H.) London: Penquin Books.

Başbay, M. (2013). Epistemolojik inancın eleştirel düşünme ve üstbiliş ile ilişkisinin yapısal eşitlik modeli ile incelenmesi. Eğitim ve Bilim, 38(169), 249-262.

Baxter Magolda, M. (1992). Knowing and reasoning in college: Gender-related patterns in students' intellectual development. San Francisco: Jossey-Bass.

Bochenski, J. M. (2009). Felsefe düşünmenin yolları (1. Bask1). Ankara: BilgeSu

Brownlee, J., Purdie, N., \& Boulton-Lewis, G. (2001). Changing epistemological beliefs in pre-service teacher education students. Teaching in Higher Education, 6(2), 247-268. 
http://dx.doi.org/10.23891/efdyyu.2017.9

Burr, J. E., \& Hofer, B. K. (2002). Personal epistemology and theory of mind: Deciphering young children's beliefs about knowledge and knowing. New Ideas in Psychology, 20(2-3), 199-224.

Clark, C. (1988). Asking the rights questions about teacher preparation: Contributions of research on teacher thinking. Educational Researcher, 17, 5-12.

Collins, H., \& Pinch, T. (1993). The golem: What everyone should know about science? Cambridge: Cambridge University Press.

Davis, L. L. (1992). Instrument review: Getting the most from a panel of experts. Applied Nursing Research, 5, 194-197.

Elder, A. D. (2002). Characterizing fifth grade students' epistemological beliefs in science. In P. R. Pintrich (Eds). Personal epistemology: The psychology of beliefs about knowledge and knowing (pp. 347-364). Mahwah, NJ, USA: Lawrence Erlbaum Associates.

Güneş, G. (2014). Çocukların epistemolojik görüşlerinin ve öğrenme stillerinin Öklidyen geometrisinde modellenmesi. Yayınlanmamış doktora tezi, Hacettepe Üniversitesi, Ankara.

Güneş, G., Oz, C., \& Tugrul, B. (2012, June 18-19). The game of kings is in the service of children-chess. Paper presented at the $26^{\text {th }}$ International Council for Children's Play (ICCP-2012), Tallinn, Estonia.

Hofer, B. (2001). Personal epistemology research: Implications for learning and teaching. Journal of Educational Psychology Review, 13, 353-383.

Hofer, B. K., \& Pintrich, P. (2002). Personal epistemology: The psychology of beliefs about knowledge and knowing. Mahwah, NJ: Lawrence Erlbaum. 
http://dx.doi.org/10.23891/efdyyu.2017.9

ISSN:1305-020

Hofer, B. K., \& Pintrich, P. R. (1997). The development of epistemological theories: Beliefs about knowledge and knowing and their relation to learning. Review of Educational Research, 67, 88-140.

Johnson, K. E., Scott, P., \& Mervis, C. B. (2004). What are theories for? Concept use throughout the continuum of dinosaur expertise. Journal of Experimental Child Psychology, 87, 171-200.

Johnston, P, Woodside-Jiron, H., \& Day, J. (2001). Teaching and learning literate epistemologies. Journal of Educational Psychology, 93, 223-233.

Joseph, G. E., \& Strain, P. S. (2010). Teaching young children interpersonal problem- solving skills. Young Exceptional Children, 13(3), 28-40.

Kale, N. (2009). Felsefiyat (1. Baskı). Ankara: Pegem Akademi.

Karasar, N. (2013). Bilimsel araştırma yöntemi (25. Baskı). Ankara: Nobel Yayın Dağıtım.

King, P., \& Kitchener, K. (1994). Developing reflective judgment: Understanding and promoting intellectual growth and critical thinking in adolescents and adults. San Francisco: Jossey-Bass.

Kuhn, D. (1991). The skills of argument. Cambridge: Cambridge University Press.

Louca, L., Elby, A., Hammer, D., \& Kagey, T. (2004). Epistemological resources: Applying a new epistemological framework to science instruction. Educational Psychologist, 39, $57-68$.

Mesleki Eğitim ve Öğretimi Güçlendirme Projesi (MEGEP) (2007). Çocuk Gelişimi ve Eğitimi, Bilişsel Gelişim, MEB, Ankara.

Perry, W. G. (1999). Forms of intellectual and ethical development in the college years: A scheme. San Francisco: Josey-Bass. 
http://dx.doi.org/10.23891/efdyyu.2017.9

Perry, W. G. (1981). Cognitive and ethical growth: The making of meaning. In A. W. Chickering \& Assoc. (Eds). The modern American college (pp. 76-116). San Francisco: Jossey-Bass.

Piaget, J. (1970). Science of education and the psychology of the child. New York: Orion Press.

Piaget, J. (1964). The early growth of logic in the child. London: Routledge and Kegan Paul Ltd.

Ravindran, B., Greene, B. A. \& DeBacker, T. K. (2005). The role of achievement goals and epistemological beliefs in the prediction of pre-service teacher's cognitive engagement and application learning. Journal of Educational Research, 98(4), 222-233.

Schommer, M. (1993). Epistemological development and academic performance among secondary students. Journal of Educational Psychology, 85(3), 406-411.

Schommer, M. (1990). Effects of beliefs about the nature of knowledge on comprehension. Journal of Educational Psychology, 82, 498-504.

Schraw, G. (2001). Current themes and future directions in epistemological research: A commentary. Educational Psychology Review, 13(4), 451-464.

Schraw, G., \& Sinatra, G. M. (2004). Epistemological development and its impact on cognition in academic domains. Contemporary Educational Psychology, 29, 95-102.

Sönmez, V. (2010). Bilim felsefesi. Ankara: Anı Yayıncılık.

Sözer, Ö. (2009). Felsefenin abc'si (4. Bask1). İstanbul: Say Yayınları.

Stemmler, R. (2006). The power to educate and inspire. Alcheringa, Special Publication, 1, $307-312$

Tekin, H. (1993). Ĕ̌itimde ölçme ve değerlendirme. Ankara: Yarg1 Yayınevi. 
http://dx.doi.org/10.23891/efdyyu.2017.9

ISSN:1305-020

Topdemir, H. G. (2011). Felsefe (2. Baskı). Ankara: Pegem Akademi.

Torrance, E. P. (1972). Can we teach children to think creatively?. The Journal of Creative Behavior, 6, 114-143.

Toulmin, S. E. (1990). The uses of argument (10th Ed.). Cambridge: Cambridge University Press.

Tuğrul, B., Güneş, G., Tokuç, H., ve Boz, M (2012). Merak öğrenmeyi başlatır. Çăğdaş Eğitim Dergisi Akademik, 1(4), 20-31.

Weinstock, M. P., Neuman, Y., \& Glasser, A. (2006). Identification of informal reasoning fallacies as a function of epistemological level, grade level, and cognitive ability. Journal of Educational Psychology, 98(2), 327-341.

White, D. A. (2010). Çocuklar için felsefe: Her şey hakkında merak uyandıracak 40 eğlenceli soru (3. Bask1). Ankara: ODTÜ Yayıncılık.

Yang, F. Y., \& Tsai, C. C. (2010). Reasoning about science-related uncertain issues and epistemological perspectives among children. Instructional Science, 38(4), 325-354. 